DOI: $10.17951 /$ lrp.2018.37.3.61-78

\author{
IZABELLA KUCHARCZYK \\ Akademia Pedagogiki Specjalnej im. M. Grzegorzewskiej w Warszawie \\ ttps://orcid.org/0000-0003-1054-9825
}

\title{
ROZUMOWANIE PRZEZ ANALOGIE SEMANTYCZNE W KATEGORII PRZYCZYNA - SKUTEK W GRUPIE UCZNIÓW NIEWIDOMYCH
}

\begin{abstract}
Streszczenie: Rozumowanie przez analogie odgrywa ogromną rolę w życiu osób niewidomych. Ponieważ osoby widzące posługują się słownictwem i wyrażeniami obejmującymi relacje pomiędzy wszystkimi zmysłami, niewidomi muszą w jak najlepszy dla siebie sposób poznać te wyrażenia. Umożliwia im to właśnie analogia. Rozumowanie przez analogie rozwija i poszerza zakres słownictwa (czynnego i biernego), umożliwia poznawanie określonych relacji pomiędzy przedmiotami, pojęciami i zjawiskami, dzięki czemu tworzona wizja rzeczywistości jest bardziej adekwatna. Przebadanych zostało 63 uczniów niewidomych i 63 uczniów widzących w wieku 10-14 lat. Zastosowano Testy do badania rozumowania przez analogie semantyczne B. Pietrulewicza. Wraz z wiekiem rozumowanie przez analogie semantyczne uczniów niewidomych doskonali się, co jest między innymi skutkiem przechodzenia z etapu myślenia konkretnego na etap myślenia formalnego. Następuje wtedy uaktywnienie różnorakich operacji myślowych, w tym coraz precyzyjniejsze wykorzystywanie analogii.
\end{abstract}

Słowa kluczowe: analogie, rozumowanie przez analogie semantyczne, analogie semantyczne w kategorii przyczyna - skutek, uczniowie niewidomi

\section{WPROWADZENIE}

W podręcznikach tyflopsychologii i tyflopedagogiki (Walthes 2007) można przeczytać, że niewidomi żyją w świecie analogii. Świat ich zubożony jest o informacje wzrokowe, przez co najważniejszymi zmysłami są dotyk i słuch. W psychologii rozumowanie przez analogie to struktura, która pojawia się dopiero w stadium operacji konkretnych. Analogia wiąże się ściśle z ugrupowaniami takimi jak seriacja czy klasyfikacja (Nęcka, Orzechowski, Szymura 2006). Zdolność ro- 
zumowania przez analogie zależy od wieku, umiejętności interpretacji, szukania relacji w zakresie różnych dziedzin nauk, zdolności do integracji wiedzy, kontroli dystraktorów (Richland, Morrison, Holyoak 2006).

Rozumowanie przez analogie stanowi jedno z głównych źródeł poznawania świata przez osoby niewidome, dlatego tak ważne jest zrozumienie jego istoty. Analogia wykorzystywana np. w wyobrażeniach surogatowych umożliwia zestawianie razem różnych cechy przedmiotu. Niewidomy od najmłodszych lat widzi te różnice i podobieństwa często tam, gdzie osoba widząca nie jest w stanie ich dostrzec i na tej podstawie tworzy swój obraz świata zewnętrznego. Dzięki rozumowaniu przez analogie niewidomy wzbogaca swoją wiedzę o otaczających go zjawiskach i przedmiotach. A im więcej posiada na ich temat wiadomości cząstkowych, tym obraz jest pełniejszy (Sękowska 1998). Rozumowanie przez analogie rozwija i poszerza zakres słownictwa (czynnego i biernego), umożliwia poznawanie określonych relacji pomiędzy przedmiotami, pojęciami, zjawiskami, dzięki czemu tworzona wizja rzeczywistości jest bardziej adekwatna.

Zdaniem B. Miles i B. McLetchie (2004) rozumowanie przez analogie u niewidomych zaczyna rozwijać się i być wykorzystywane w wyniku zbieranych doświadczeń. Ich brak drastycznie wpływa nie tylko na trudności w rozumowaniu przez analogie oraz na zdolność do tworzenia nowych konstruktów, koncepcji, relacji między nimi, ale także na brak umiejętności znalezienia luk w wiedzy i uzupełnianie jej.

B. Landau (1997) uważa, że poziom rozwoju mowy, jej składnia i gramatyka rozwijają się tak samo jak u widzących, ale podstawowym problemem w grupie niewidomych jest brak rozumienia odniesienia w zdaniu, czyli analogii. Z kolei J.M. Iverson i S. Goldin-Meadow (1997; 2005) twierdzą, że uczniowie niewidomi nie tylko mają obniżoną gestykulację podczas wyjaśniania pojęć, ale także podczas ich definiowania użyją analogii jako strategii interferencji.

Rozumowanie przez analogie u uczniów niewidomych badała także m.in. K. Jaworska-Biskup (2010). Jej zdaniem niewidomi, opisując pojęcia, odwołują się do związków nieliteralnych, np. utożsamiają dane pojęcie z kolorem. Podobne badania prowadziła I. Parulska (2010): dotyczyły one rozumowania przez analogie na materiale semantycznym w kategorii część - całość. Uczniowie niewidomi osiągnęli wyższe wyniki od widzących rówieśników w próbach dotyczących wiedzy przyrodniczej, ogólnej i przestrzennej, niższe natomiast - w pozostałych próbach związanych z relacjami przestrzennymi i relacją czasową.

Badania w tym zakresie podjęli także M. Knauff i E. May (2004; 2006), którzy przeprowadzili 3 eksperymenty dotyczące wykorzystywania analogii w relacji przestrzennych w grupie uczniów niewidomych. Uczeni stwierdzili, że poznawanie i rozumowanie werbalne relacji przestrzennych jest możliwe w grupie niewidomych, 
ale tylko wtedy, gdy zastosowana zostanie analogia. Jak twierdzi G. Lakoff (1990), aby niewidomy mógł zrozumieć pojęcia rozumiane przez widzących, potrzebna jest mu właśnie analogia.

Badania dotyczące rozumowania przez analogie u niewidomych w literaturze polskiej jak i zagranicznej są rzadko opisywane przez tyflopsychologów. Wynika to najprawdopodobniej z braku technik badawczych umożliwiających przeprowadzenie takich badań. Chęć poznania, zrozumienia i rozszerzenia wiedzy na temat, w jaki sposób niewidomi uczniowie rozumują przez analogie na materiale semantycznym w kategorii przyczyna - skutek stała się podstawą do podjęcia badań w tym zakresie.

\section{PROBLEMY BADAWCZE}

Celem niniejszej pracy jest empiryczne poznanie i analiza rozumowania przez analogie semantyczne w kategorii przyczyna - skutek u uczniów niewidomych. Osiągnięcie tego celu wiąże się z uzyskaniem odpowiedzi na następujące pytania badawcze: Jakie jest rozumowanie przez analogie semantyczne w kategorii przyczyna - skutek u uczniów niewidomych w III i V klasie szkoły podstawowej oraz I klasie gimnazjum? Czy i jakie istnieją różnice w zakresie rozumowania przez analogie w kategorii przyczyna - skutek między uczniami niewidomymi i widzącymi w III i V klasie szkoły podstawowej oraz I klasie gimnazjum? Czy występuje, a jeśli tak, to jaka, zależność pomiędzy rozumowaniem przez analogie semantyczne w kategorii przyczyna - skutek u uczniów niewidomych a ich okresem pobytu w danej placówce (internacie) i osiągnięciami edukacyjnymi?

W literaturze polskiej i zagranicznej nie ma zbyt wielu doniesień empirycznych na temat rozumowania przez analogie u uczniów niewidomych. Nie opublikowano dotychczas żadnych analiz odnoszących się do zależności pomiędzy rozumowaniem przez analogie semantyczne a takimi zmiennymi jak: okres pobytu w placówce (internacie) czy osiągnięcia edukacyjne, dlatego też można jedynie zakładać istotną statystycznie zależność pomiędzy wyżej wspomnianymi zmiennymi. Można przypuszczać, że im dłuższy okres pobytu w danej placówce (internacie), tym większe możliwości zdobywania kompetencji potrzebnych do sprawnego wykorzystywania rozumowania przez analogie w wyniku systematycznego treningu i fachowej pomocy. Z kolei im uczeń bardziej adekwatnie stosuje analogie, tym szybciej zdobywa nową wiedzę, co przekłada się na jego osiągnięcia edukacyjne. 


\section{METODA}

Zastosowano kwestionariusz wynikający z postawionych problemów badawczych i specyfiki badanej grupy. Jest to Test do badania analogii werbalnych konstrukcji B. Pietrulewicza (1983), pozwalający określić wykorzystywanie analogii opartych na materiale semantycznym; przeznaczony dla grupy niewidomych i widzących w wieku szkolnym.

W zakresie analogii opartych na materiale semantycznym w kategorii przyczyna -skutek wyodrębniono 12 prób (tabela 1), z których 6 ma charakter skutkowoprzyczynowy (próby nieparzyste: $1,3,5,7,9,11)$ i 6 przyczynowo-skutkowym (próby parzyste: 2, 4, 6, 8, 10,12). Dodatkowo określono, jakiej wiedzy wyżej wymienione próby dotyczą: stanów emocjonalnych (próba 2), wiedzy ogólnej (próby $1,7,8,9,10,12$ ), wiedzy przyrodniczej (próby 3, 4, 5, 6, 11). Wszystkie próby (12) były czytane zarówno uczniom niewidomym jak i widzącym na głos. Ich zadaniem było podanie analogii do ostatniego w próbie wyrazu, w oparciu o znalezienie uprzednio relacji między pierwszą parą wyrazów.

Tabela 1. Zadania rozwiązywane przez uczniów niewidomych i widzących badające rozumowanie przez analogie semantyczne w kategorii przyczyna - skutek

\begin{tabular}{|l|l|c|l|l|l|l|l|}
\hline Nr próby & \multicolumn{7}{|c|}{ Zadania } \\
\hline 1 & dom & - & architekt & $::$ & książka & - & \\
\hline 2 & smutek & - & płacz & $::$ & radość & - & \\
\hline 3 & lód & - & mrozy & $::$ & powódź & - & \\
\hline 4 & ulewa & - & mokry & $::$ & upał & - & \\
\hline 5 & deszcz & - & chmura & $::$ & katar & - & \\
\hline 6 & ogień & - & ciepło & $::$ & błyskawica & - & \\
\hline 7 & wiedza & - & uczyć się & $::$ & zmęczenie & - & \\
\hline 8 & trucizna & - & śmierć & $::$ & pokarm & - & \\
\hline 9 & wypadek & - & nieostrożność & $::$ & głód & - & \\
\hline 10 & zdarzenie & - & wspomnienie & $::$ & pożar & - & \\
\hline 11 & zapach & - & kwiat & $::$ & blask & - & \\
\hline 12 & instrument & - & dźwięk & $::$ & bomba & - & \\
\hline
\end{tabular}

Wskaźnikiem dla zmiennej okres pobytu w placówce (w internacie) była informacja uzyskana z dokumentacji szkolnej o czasie, jaki uczeń spędził w placówce.

Wskaźnikiem dla zmiennej osiągnięcia edukacyjne uczniów (III i V klasy szkoły podstawowej oraz I gimnazjum) była średnia ocen półrocznych i końcowych rocznych uzyskana przez badanych uczniów z poszczególnych przedmiotów. 


\section{CHARAKTERYSTYKA OSÓB BADANYCH}

Badaniami objęto 126 uczniów ${ }^{1}$. Grupę podstawową stanowiło 63 uczniów niewidomych w wieku 10 lat (III klasa szkoły podstawowej), 12 lat (V klasa szkoły podstawowej) i 14 lat (I klasa gimnazjum). Podzielono ich na trzy kategorie wiekowe, po 21 osób. Uczniowie niewidomi byli to wszyscy uczniowie z całej Polski uczący się w 7 specjalnych ośrodkach szkolno-wychowawczych, dlatego też podział na grupy był celowy. Grupa uczniów niewidomych pod względem płci nie była równoliczna - chłopców było 25, a dziewcząt 38 .

Wśród 21 badanych trzecioklasistów 9 (42,9\%) przebywało w internacie od 4 lat, czyli od rozpoczęcia nauki w klasie „0”, 2 osoby $(9,5 \%)$ przebywały tam 3 lata, 7 osób $(33,3 \%)$ - 2 lata, 2 osoby $(9,5 \%)$ - 1 rok. W klasie V szkoły podstawowej 4 osoby (19\%) były mieszkańcami ośrodka od 6. roku życia, 7 (33,3\%) - od I klasy, 1 (4,8\%) - od II klasy, 5 (23,8\%) - od III klasy, 2 (9,5\%) - od IV klasy, 2 osoby (9,5\%) nie mieszkały w ośrodku nigdy. Wśród gimnazjalistów 8 uczniów $(38,1 \%)$ przebywało w ośrodku 7 lat, czyli od I klasy, 6 (28,6\%) - od 6 lat, 3 (14,2\%) - od 5 lat, $1(4,8 \%)$ - od 4 lat, $1(4,8 \%)$ - od roku, dwoje mieszkało poza ośrodkiem.

Grupę porównawczą stanowiło 63 uczniów widzących podzielonych na takie same grupy wiekowe i liczbowe. Dobór do grupy porównawczej był celowo - losowy, ponieważ dobrano ją pod względem liczebności, płci, klasy i miejsca zamieszkania w odniesieniu do uczniów niewidomych.

Przy doborze osób do grupy przestrzegano wyznaczonych uprzednio kryteriów: istnienie lub brak uszkodzenia wzroku (w przypadku uczniów z uszkodzonym wzrokiem grupę badawczą stanowią osoby niewidome od urodzenia bądź też te, które utraciły wzrok przed 5. rokiem życia); wiek i klasa (10 lat - III klasa szkoły podstawowej; 12 lat - V klasa szkoły podstawowej i 14 lat - I klasa gimnazjum); prawidłowy rozwój intelektualny; typ szkoły (specjalny ośrodek szkolno-wychowawczy dla uczniów niewidomych; szkoła ogólnodostępna dla uczniów widzących); brak dodatkowych schorzeń.

\section{WYNIKI BADAŃ}

Średnia wartość uzyskana przez 63-osobową grupę uczniów niewidomych w zakresie analogii semantycznych w kategorii przyczyna - skutek wyniosła 5,52. Wartość ogólnej średniej stanowi 43,75\% wyniku możliwego do uzyskania. Wyniki odchylają

${ }^{1}$ Badania zostały przeprowadzone w roku szkolnym 2007/2008 i stanowią fragment badań zrealizowanych w ramach rozprawy doktorskiej. W Polsce od tego czasu nie podejmowano badań na temat analogii semantycznych. 
się o 2,39, a przedział dla wyników średnich wynosi od 2,86 do 7,91. Minimalny wynik osiągnięty przez badaną grupę wyniósł 0 a maksymalny - 11 punktów. Należy dodać, że różnica pomiędzy maksimum a minimum wyniosła aż 11 punktów. Dane dotyczące analogii semantycznych kategorii przyczyna - skutek zostały zaprezentowane w tabeli 2 .

Tabela 2. Wyniki uzyskane przez uczniów niewidomych w zakresie analogii semantycznych w kategorii przyczyna - skutek

\begin{tabular}{|l|c|c|c|c|c|c|c|c|}
\hline \multicolumn{1}{|c|}{ Wiek } & N & $\begin{array}{c}\text { Wynik max. } \\
\text { możliwy do } \\
\text { uzyskania }\end{array}$ & M & SD & $\begin{array}{c}\text { M:M } \\
\text { max } \\
(\%)\end{array}$ & Min. & Max. & $\begin{array}{c}\text { Xtyp } \\
(\mathbf{M} \pm \text { Sd })\end{array}$ \\
\hline ogólny wynik & 63 & 12 & 5,52 & 2,39 & 46,00 & 0 & 11 & $2,86-7,91$ \\
\hline 10 lat - III kl. SP & 21 & 12 & 4,29 & 2,07 & 35,75 & 0 & 8 & $2,22-6,38$ \\
\hline 12 lat - V kl. SP & 21 & 12 & 5,05 & 2,50 & 42,08 & 1 & 11 & $2,55-7,55$ \\
\hline 14 lat - I kl. gim. & 21 & 12 & 7,24 & 1,51 & 60,33 & 4 & 11 & $5,73-8,75$ \\
\hline
\end{tabular}

Objaśnienia do tabeli: N - liczba osób; M - średnia arytmetyczna; SD - odchylenie standardowe; Min. - najmniejszy wynik uzyskany w danej kategorii; Max. - największy wynik uzyskany w danej kategorii; $\mathrm{X}_{\text {typ }}$ - granice obszaru typowego

Na podstawie danych (tabela 2) można stwierdzić, że największy przyrost sprawności związanych $\mathrm{z}$ rozumowaniem przez analogie oparte na materiale semantycznym w kategorii przyczyna - skutek przypada między V klasą szkoły podstawowej a I klasą gimnazjum.

Dokonując analizy wartości wskaźnika testu F - jednoczynnikowej analizy wariancyjnej (ANOVA) - stwierdzono, że istnieje statystycznie istotna różnica dotycząca rozumowania przez analogię w kategorii przyczyna - skutek pomiędzy trzema grupami wiekowymi uczniów niewidomych $(\mathrm{F}(2 ; 60)=11,515, \mathrm{p}<0,05)$. Uzupełnieniem obrazu rozumowania przez analogie w kategorii przyczyna - skutek w poszczególnych grupach wiekowych są wyniki testu Tukeya zaprezentowane w tabeli 3.

Tabela 3. Wyniki analizy różnic pomiędzy grupami uczniów niewidomych w zakresie rozumowania przez analogie semantyczne w kategorii przyczyna - skutek

\begin{tabular}{|l|c|c|}
\hline $\begin{array}{c}\text { Porównywane grupy } \\
\text { (uczniowie niewidomi, klasa) }\end{array}$ & Różnica średnich & $\begin{array}{c}\text { Istotność statystyczna } \\
\text { na poziomie 0,05 }\end{array}$ \\
\hline III SP i V SP & $-0,762$ & 0,462 \\
\hline III SP i I gimn. & $-2,952$ & $0,000^{*}$ \\
\hline V SP i I gimn. & $-2,190$ & $0,003^{*}$ \\
\hline
\end{tabular}


Stwierdzono, że istnieją istotne statycznie różnice w zakresie rozumowania przez analogie w kategorii przyczyna - skutek pomiędzy uczniami niewidomymi w wieku 10 lat (III klasa szkoły podstawowej) i 14 lat (I klasa gimnazjum; $\mathrm{p}<0,05)$. Wskazano również na różnicę istotną statystycznie pomiędzy uczniami niewidomymi w klasie V szkoły podstawowej (12 lat) i uczniami w I klasie gimnazjum (14 lat; $\mathrm{p}<0,05)$. Nie wykazano istotnych statystycznie różnic pomiędzy grupą uczniów niewidomych w klasie III i klasie V szkoły podstawowej. Wartości średnich arytmetycznych uzyskane w badaniach empirycznych pozwalają zauważyć, że największe umiejętności w zakresie rozumowania przez analogie semantyczne w kategorii przyczyna - skutek posiadają uczniowie klas I gimnazjum $(M=7,24)$, a najmniejsze uczniowie klasy III szkoły podstawowej $(M=4,29)$. Może to wynikać z tego, że uczniowie z niepełnosprawnością wzroku w III klasie szkoły podstawowej mogą nie mieć wystarczającej wiedzy, nie potrafią jeszcze dokonywać operacji na materiale abstrakcyjnym, co wiąże się z późniejszym osiąganiem stadium operacji formalnych i umiejętnością transformacji, antycypacji, reprodukcji informacji.

Ponieważ na podstawie przeprowadzonej analizy statystyk opisowych nie można przedstawić jednoznacznych wniosków co do istotności różnic pomiędzy średnimi wynikami uzyskanymi przez badane grupy, w tym celu zastosowano test t-Studenta dla grup niezależnych. Szczegółowe dane dotyczące omawianych podgrup uczniów niewidomych i widzących zaprezentowano w tabeli 4 .

Na podstawie wyników uzyskanych z testu t-Studenta stwierdzono tylko jedną różnicę istotną statystycznie dotyczącą rozumowania przez analogie w zakresie relacji przyczyna - skutek - pomiędzy uczniami niewidomymi a widzącymi w wieku 10 lat, czyli w III klasie szkoły podstawowej $\mathrm{t}(40)=-2,077 ; \mathrm{p}<0,05$.

Tabela 4. Porównanie wyników analogii semantycznych w kategorii przyczyna skutek w grupie osób niewidomych i widzących

\begin{tabular}{|c|c|c|c|c|c|c|c|}
\hline \multirow{2}{*}{ Wiek } & \multirow{2}{*}{ Grupa } & \multirow{2}{*}{$\mathbf{N}$} & \multirow{2}{*}{$\mathbf{M}$} & \multirow{2}{*}{ SD } & \multicolumn{3}{|c|}{ Wynik testu t-Studenta } \\
\hline & & & & & wartość t & df & p \\
\hline \multirow{2}{*}{10 lat, III kl. SP } & niewidomi & 21 & 4,29 & 2,077 & \multirow{2}{*}{2,107} & \multirow{2}{*}{40} & \multirow{2}{*}{$0,041^{*}$} \\
\hline & widzący & 21 & 3,10 & 1,546 & & & \\
\hline \multirow{2}{*}{12 lat, V kl. SP } & niewidomi & 21 & 5,05 & 2,500 & \multirow{2}{*}{$-0,868$} & \multirow{2}{*}{40} & \multirow{2}{*}{0,390} \\
\hline & widzący & 21 & 5,62 & 1,687 & & & \\
\hline \multirow{2}{*}{14 lat, I kl. gim. } & niewidomi & 21 & 7,24 & 1,513 & \multirow{2}{*}{1,509} & \multirow{2}{*}{40} & \multirow{2}{*}{0,139} \\
\hline & widzący & 21 & 6,43 & 1,938 & & & \\
\hline
\end{tabular}

Objaśnienia do tabeli: $\mathrm{N}$ - liczebność grupy; M - średnia arytmetyczna; SD - odchylenie standardowe; $\mathrm{df}$ - stopnie swobody; $\mathrm{p}$ - poziom istotności; ${ }^{*}$ - istotność statystyczna na poziomie 0,05 
Pomiędzy uczniami niewidomymi a widzącymi w wieku 12 i 14 lat nie określono istotnych statystycznie różnic $\mathrm{w}$ zakresie rozumowania przez analogie $\mathrm{w}$ kategorii przyczynowo-skutkowej. Na podstawie wartości średnich arytmetycznych można jedynie stwierdzić, że uczniowie widzący $\mathrm{z}$ klasy $\mathrm{V}(\mathrm{M}=5,62)$ uzyskują wyższe wyniki od swoich niewidomych rówieśników. Natomiast uczniowie niewidomi $\mathrm{w}$ wieku 14 lat $(\mathrm{M}=7,24)$ osiągają wyższe rezultaty od uczniów widzących w takim samym wieku.

Otrzymany materiał empiryczny pozwala również na stwierdzenie, że największa dyspersja wyników wśród uczniów niewidomych przypada na klasę V, natomiast maleje w I klasie gimnazjum, osiągając wartość 1,5 punktu. Natomiast w grupie uczniów widzących największa dyspersja wyników przypada na klasę I gimnazjum i jest wprost proporcjonalna do wieku uczniów, tj. rośnie wraz z wiekiem. Na podstawie średnich arytmetycznych określono, że największy wzrost wyników w grupie uczniów niewidomych przypada na okres między V klasą szkoły podstawowej a I gimnazjum. Natomiast w grupie uczniów widzących jest odwrotnie, największy wzrost wyników przypada na okres między III a V klasą szkoły podstawowej.

W zakresie rozumowania przez analogie semantyczne w kategorii przyczyna - skutek u uczniów niewidomych $(\mathrm{N}=63)$ występuje również zależność między wynikami a okresem pobytu w internacie. Jest to zależność istotna statystycznie, dodatnia, o sile wyraźnej, lecz mała ( $\mathrm{r}$ Spearmana $=0,379 ; \mathrm{p}<0,05)$. Oznaczać to może, że im dłuższy jest okres pobytu w placówce (internacie), tym wyższe wyniki w omawianej kategorii analogii osiągają uczniowie niewidomi. Natomiast w podziale na kategorie wiekowe (klasowe) istnieje dodatnia, umiarkowana, statystycznie istotna zależność pomiędzy rozumowaniem przez analogie semantyczne w kategorii przyczyna - skutek $(\mathrm{r}=0,489 ; \mathrm{p}<0,05)$ a okresem pobytu w internacie. Im dłuższy okres pobytu ucznia w ośrodku, tym uzyskuje on wyższe wyniki w zakresie omawianej kategorii analogii.

$\mathrm{Z}$ analizy danych empirycznych wynika również, że istnieje istotna statystycznie zależność pomiędzy rozumowaniem przez analogie semantyczne w kategorii przyczyna - skutek a osiągnięciami edukacyjnymi uczniów niewidomych. Zależność taka jest tylko jedna - w grupie uczniów uczących się w III klasie szkoły podstawowej $(\mathrm{N}=21$; r Spearmana $=0,453, \mathrm{p}<0,05)$. Oznacza to, że im wyższa jest średnia ocen ucznia, tym osiąga on wyższe wyniki w zakresie rozumowania przez analogie semantyczne w kategorii przyczyna - skutek. Może to wynikać z tego, że potrafi on na materiale semantycznym dokonywać różnych operacji umysłowych, a to przekłada się na wyższe osiągnięcia edukacyjne i na poprawne rozwiązywanie zadań w kategorii przyczyna - skutek.

Na podstawie danych przedstawionych w tabeli 5 można stwierdzić, że uczniowie niewidomi osiągnęli wyższe wyniki w porównaniu z widzącymi rówieśnikami 
w następujących zadaniach: $2(M=13), 3(M=14,33), 4(M=11,66), 6(M=8,33)$, $8(\mathrm{M}=8,33), 11(\mathrm{M}=12,33)$ i $12(\mathrm{M}=11,33)$. W pozostałych próbach, czyli $1(\mathrm{M}=9,66), 5(\mathrm{M}=6,66), 7(\mathrm{M}=6,33), 9(\mathrm{M}=6,33), 10(\mathrm{M}=6)$ uczniowie niewidomi osiągnęli wyniki niższe. Najtrudniejszymi zadaniami, w których zarówno uczniowie niewidomi, jak i widzący popełnili najwięcej błędów, są próby: $5,6,7,8,9$, 10. Dla uczniów niewidomych łatwymi zadaniami okazały się próby: $2,3,4,11,12$, a dla uczniów widzących - 1 i 3 .

Tabela 5. Średnie wyniki w grupie uczniów niewidomych $(\mathrm{N}=63)$ i widzących $(\mathrm{N}=63)$ w zakresie rozumowania przez analogie semantyczne w kategorii przyczyna - skutek

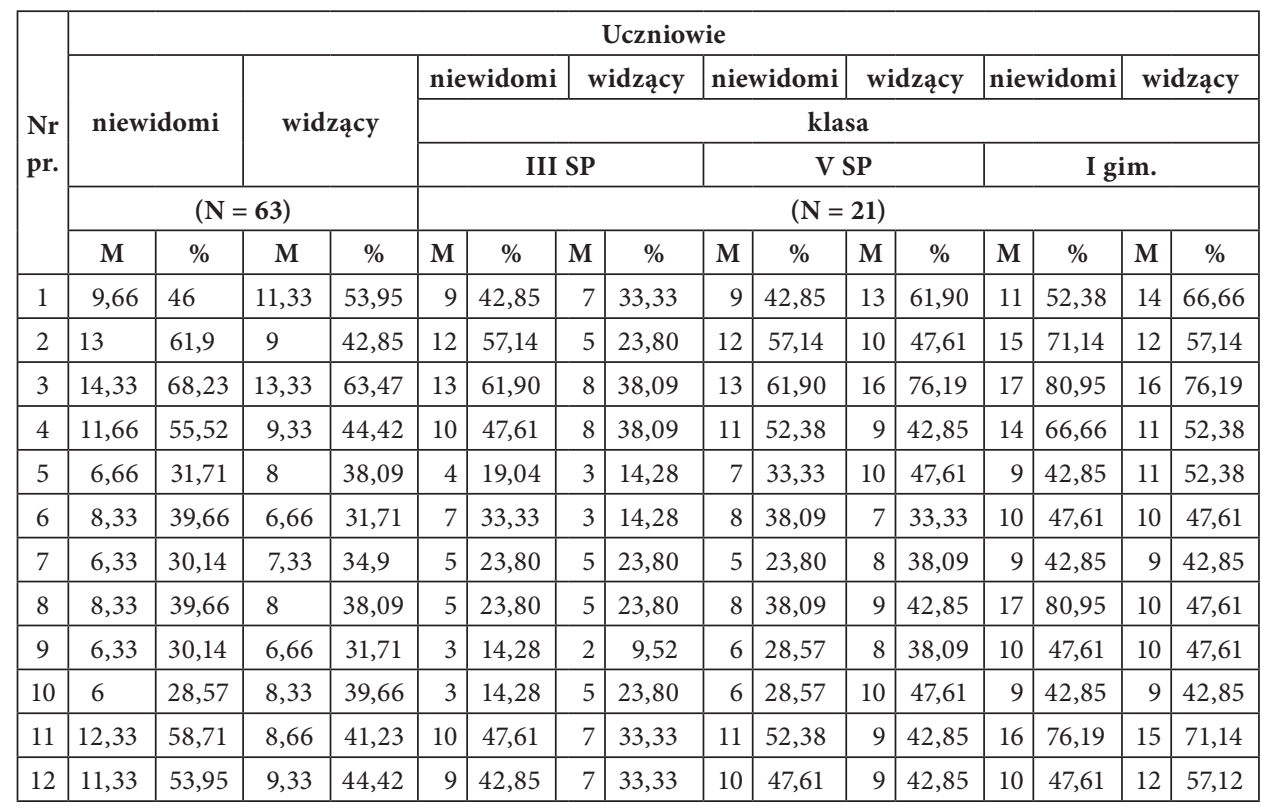

Objaśnienia do tabeli: $\mathrm{N}$ - liczba osób; \% - procent

Zebrany materiał empiryczny dotyczący rozumowania przez analogie w kategorii przyczyna - skutek pozwolił na dokonanie szczegółowej analizy odpowiedzi udzielanych przez uczniów niewidomych i widzących.

Próby nieparzyste mają charakter skutkowo-przyczynowy, a próby parzyste prezentują relację przyczyna - skutek. Najpierw omówię wyniki badań w zakresie prób nieparzystych $(1,3,5,7,9,11)$ a w dalszej kolejności - parzystych $(2,4,6$, $8,10,12)$. W obrębie tej kategorii próby odnoszą się do stanów emocjonalnych (próba 2), wiedzy ogólnej (próba: 1, 7, 8, 9, 10, 12), wiedzy przyrodniczej (próby $3,4,5,6,11)$. 
PRÓBY NIEPARZYSTE $(1,3,5,7,9,11)$

Próba 1: (dom - architekt :: książka - ...?) dotyczy wnioskowania ze skutku o przyczynie. W tym przypadku uczniowie niewidomi z III i V klasy osiągnęli wynik równy 9 punktom $(42,85 \%)$. Natomiast w I gimnazjum wynik ten zwiększony został jedynie o 2 punkty. Jeśli chodzi o rezultaty uczniów widzących, to osiągnęli oni w III klasie wynik niższy o 2 punkty od swoich niewidomych rówieśników, natomiast $\mathrm{w} \mathrm{V}$ klasie różnica między uczniami $\mathrm{z}$ dwóch porównywanych grup wynosiła 4 punkty na korzyść grupy widzących. Również w klasie I gimnazjum uczniowie widzący uzyskali wyższe rezultaty. Aby rozwiązać to zadanie poprawnie, należało przenieść relację wykrytą $\mathrm{w}$ pierwszej parze wyrazów na drugą. W przypadku uczniów niewidomych błędy były następujące: pierwsza grupa to wskazywanie wyrazów należących do tej samej klasy wyrazów związanych z terminem książka, np. opowiadanie, bajka, wiersz, przygodowa książka, gazeta, czasopismo, słownik, encyklopedia, księga, litery, okładka, tom. Druga grupa popełnianych błędów to wymienianie elementów, które wykorzystywane są do tworzenia książek, np. długopis, pióro, blok, kartka, zeszyt, brudnopis. Kolejna grupa błędów to wskazywanie na miejsce, w którym wypożycza się książki i na osoby, które mogą korzystać z książek, np. biblioteka, archiwum, regał, szkoła, czytelnik, uczeń.

Próba 3 (lód-mrozy :: powódź - ...?). Zadaniem uczniów było uzupełnienie analogii informacjami o zjawiskach atmosferycznych występujących w przyrodzie. Uczniowie niewidomi z III i V klasy zdobyli po 13 punktów (61,90\%). Widzące dziesięciolatki osiągnęły rezultaty niższe od niewidomych rówieśników o 5 punktów. Z kolei widzący piątoklasiści zebrali o 3 punkty więcej. Uczniowie niewidomi z I klasy gimnazjum osiągnęli wyniki wyższe o 1 punkt od swych rówieśników. Błędne odpowiedzi jakich udzielili uczniowie z uszkodzonym wzrokiem, mogą po pierwsze odnosić się do pierwszej relacji, np. śnieg, śnieżnie, zimno. Po drugie uczniowie tworzyli analogie na zasadzie dobierania wyrazów przeciwstawnych: ciepło, goraco, upalnie. Po trzecie odpowiedzi odwoływały się wprawdzie do terminu powódź, ale uczniowie wymieniali poszczególne zbiorniki wodne, np. ocean, morze, rzeka i jezioro. Bardzo ciekawe wydają się odpowiedzi, które nawiązują do sytuacji w trakcie powodzi. Niektórzy uczniowie wymieniali takie przedmioty jak łódka, wędka. Odpowiedzi uczniów widzących są bardzo zbliżone. Najbardziej interesujące odpowiedzi podawane przez uczniów widzących to: przyplyw i odplyw oraz tornado, czyli zjawiska występujące w przyrodzie. Najprawdopodobniej uczniowie, używając tych nazw, nie znali do końca ich znaczenia.

Próba 5 (deszcze - chmura :: katar - ...?). Wyniki, jakie osiągnęli uczniowie niewidomi i widzący, są bardzo niskie. Niewidomi uczniowie III klasy uzyskali tylko 4 punkty (19,04\%), a piątoklasiści - 7 (33,33\%). Również uczniowie w I klasie 
gimnazjum popełnili sporo błędów, co spowodowało, że uzyskali tylko 9 punktów (42,38\%). Błędy można podzielić na dwie kategorie. Do pierwszej zaliczymy błędy związane ze zmianą wnioskowania z przyczyny na skutek np. chusteczki, choroba, kichnięcie. Ten rodzaj błędów jest charakterystyczny dla starszych uczniów. Druga kategoria popełnianych błędów to powtarzanie ostatniego wyrazu katar lub też brak odpowiedzi. Jest to błąd popełniany najczęściej przez uczniów z III klasy, gdyż próba ta okazała się niezwykle trudna dla uczniów w wieku 10 lat. Dokonując porównania wyników uczniów niewidomych i widzących, należy podkreślić, że różnice w punktach są nieduże ze względu na trudność tego zadania. Uczniowie widzący w III klasie uzyskali tylko 3 punkty $(14,28 \%)$ w V klasie - 10 punktów (47,61\%), zaś w I gimnazjum 11 (52,38\%).

Próba 7 dotycząca zastosowania operacji logicznych (wiedza - uczyć się :: zmęczenie - ...?) również okazała się bardzo trudna zarówno dla niewidomych, jak i widzących. Trzecioklasiści widzący oraz niewidomi zdobyli taką samą liczbę punktów - po 5 (23,80\%). Różnica między piątoklasistami widzącymi a niewidomymi jest trzypunktowa, na korzyść tych pierwszych (8 punktów - 38,09\%). Natomiast w I klasie gimnazjum zarówno uczniowie z grupy podstawowej jak i porównawczej osiągnęli po 9 punktów (42,85\%). Błędy, jakie popełnili niewidomi, zostały podzielone na kilka typów. Pierwszy odnosi się do przeciwieństw, np. energia, pogodność, wypoczynek, nic nie robić, leniuchować, wyspanie, spanie, nudzić się, sen, aktywność, energia. Drugi typ to błędy odnoszące się do podawania synonimów należących do określonej klasy wyrazów np. wypalenie, praca, męczyć się, biegać, wysiłek. Trzeci typ błędów to te, które związane są z pierwszą parą wyrazów, np. uczyć się, nie uczyć się.

W badaniach dotyczących rozumowania przez analogie na materiale semantycznym odnoszącym się do wnioskowania ze skutku o przyczynie, najmniej poprawnych odpowiedzi udzielono w próbie 9 (wypadek - nieostrożność :: głód - ...?). W zadaniu tym uczniowie musieli odwołać się do posiadanej wiedzy i na podstawie zastosowanych operacji myślowych wnioskować ze skutku o przyczynie i odkryć konsekwencje pewnych stanów. Uczniowie niewidomi uczący się w III klasie szkoły podstawowej uzyskali tylko 3 punkty. Najczęstszymi błędnymi odpowiedziami udzielanymi przez tychże uczniów było odwołanie się do stanów fizycznych organizmu takich jak: picie, nienajedzenie się, głodny, najeść się, nic nie jeść. Dla niektórych osób analogią do wyrazu głód było zaprzeczanie, czyli nie głód. Niektórzy uczniowie, tworząc analogię, odwoływali się do stanów emocjonalnych np., smutek. Inni uczniowie tworzyli analogie na zasadzie przeciwieństwa do wyrazu trzeciego, np. dostatek. Tego typu reakcja może być wynikiem nieumiejętności przechodzenia i przenoszenia relacji z jednej kategorii analogii semantycznych na drugą. Uczniowie niewidomi w klasie V szkoły podstawowej osiągnęli wynik 
o 3 punkty wyższy od uczniów z III klasy, co dało rezultat 6 punktów (28,57\%). W tym przypadku błędy, jakie pojawiały się najczęściej, dotyczyły czynności związanych z brakiem spożywania pokarmów, np. pragnienie, głodny, suchość, ból brzucha. Rezultaty uczniów z I klasy gimnazjum są o 4 punkty wyższe od wyniku uczniów niewidomych uczących się w V klasie (10 punktów - 47,61\%). Błędne odpowiedzi udzielane przez starszych uczniów niewidomych można pogrupować w kilka kategorii. Do pierwszej z nich można zaliczyć te, które odnoszą się do miejsc, w których może pojawić się głód np. statek, biwak. Duga grupa błędów to te, które dotyczą stanów emocjonalnych wynikających z głodu, np. smutek, zniechęcenie. Kolejna grupa błędów to antonimy i synonimy związane z pojęciem głodu np. dostatek, pokarm, nasycenie, pożywienie. Czwarta i ostatnia grupa błędów to te, kiedy niewidomi dokonują zamiany relacji o charakterze skutek - przyczyna na relację odwrotną przyczyna - skutek, czego wynikiem będzie odpowiedź śmierć. Uczniowie widzący osiągnęli równie niskie wyniki, jak uczniowie niewidomi. W klasie III uzyskali tylko 2 punkty (9,52\%), czyli o 1 punkt mniej niż niewidomi rówieśnicy. W V klasie zdobytych punktów było już 8 (38,09\%). W I klasie gimnazjum uczniowie widzący osiągnęli taki sam wynik, jak uczniowie niewidomi, czyli 10 punktów (47,61\%).

W próbie 11 (zapach - kwiat :: blask - ...?), dotyczącej analogii w powiązaniu $z$ danymi odnoszącymi się do zjawisk optycznych, uczniowie niewidomi w porównaniu z uczniami widzącymi osiągnęli wyższe rezultaty w każdej kategorii wiekowej. Odsetek poprawnych rozwiązań rósł wraz z wiekiem uczniów. Największy przyrost wyników - aż 5 punktów - wystąpił pomiędzy uczniami z V klasy szkoły podstawowej i I klasy gimnazjum (gimnazjaliści osiągnęli 16 punktów; 76,19\%), zaś różnica między uczniami z I klasy gimnazjum z grupy podstawowej i porównawczej wyniosła 6 punktów na korzyść tych pierwszych. Zadanie to dawało możliwość różnych odpowiedzi, np. dla gimnazistów analogią do pojęcia blask jest słonce, młodsi wymieniali najczęściej oprócz słońca także księżyc i ogień. Błędy, które pojawiały się najczęściej, wynikały z zastosowania reguły przeciwstawieństwa, np. ciemność lub cień. Ten błąd jest typowy dla uczniów najmłodszych. Ponadto najczęściej popełniano go, gdy omawiana próba była zadawana po analogii dotyczącej zastosowania reguły przeciwstawieństwa. Oznacza to, że uczniowie, którzy popełniali ten błąd, nie potrafią jeszcze stosować różnych operacji logicznych i ich przerzutność jest niewystarczająca. Innym błędem było dodawanie do podawanego terminu blask przedrostka od, co nadaje wyrazowi zupełnie inne znaczenie i nie spełnia warunku poprawności. Dla niektórych niewidomych analogią do pojęcia blask jest obraz, malowidło, a dla innych jasność. Jeszcze inne proponują termin widmo, piorun, latarka. Przyczyną blasku może być także uroda lub lustro. 
PRÓBY PARZYSTE $(2,4,6,8,10,12)$.

Próba 2 (smutek - płacz :: radość - ...?) dotyczyła analogii w kategorii przyczyna - skutek odnoszącej się do stanów emocjonalnych, które wyrażane są na zewnątrz. W tym przypadku w każdej grupie wiekowej uczniowie niewidomi osiągnęli wyższe rezultaty w porównaniu z uczniami, którzy nie posiadają uszkodzonego narządu wzroku. Największa różnica występuje pomiędzy uczniami w III klasie, gdyż wynosi ona aż 7 punktów na korzyść uczniów niewidomych. Im uczniowie są starsi, tym różnica w wynikach zmniejsza się. Błędne odpowiedzi w tej próbie ograniczają się przede wszystkim do odpowiedzi w postaci wyrazów synonimicznych i antonimów związanych z przeżywanymi emocjami lub sytuacjami, np., złość, smutek, żal, miłość, cierpliwość, gniew, ból, niezadowolenie, przygnębienie, wesele, płacz ze szczęścia, pogodność, przyjaźń.

Próba 4 (ulewa - mokro :: upat - ...?) również dotyczy analogii, które trzeba uzupełnić relacją dotyczącą zjawisk atmosferycznych. Uczniowie niewidomi uzyskali w porównaniu z uczniami widzącymi wyniki wyższe. Największe różnice wyników pomiędzy grupą podstawową a porównawczą występują w I klasie gimnazjum, gdyż różnica ta wynosi 3 punkty na korzyść grupy podstawowej (14 punktów 66,66\%). Natomiast różnice wyników w klasach III i V wynoszą po 2 punkty. Uczniowie niewidomi, popełniając błędy, najczęściej podawali słowa będące wyrazem przeciwstawnym, np.: mróz, zimno, potop, lód. Inną tendencją w zakresie popełnianych błędów jest podawanie wyrazów synonimicznych np. ciepło, goraco, słońce, skwar. Wszystkie wymienione wyżej błędy występują zarówno w grupie podstawowej jak i porównawczej z podobnym natężeniem.

W próbie 6 (ogień - ciepło :: błyskawica - ...?) analizowane jest tworzenie analogii, które dotyczą odwołania się do wiedzy przyrodniczej, wykrycia relacji odnoszącej się do wnioskowania o skutku na podstawie podanej przyczyny, a także zastosowania operacji logicznych. Z przeprowadzonych badań wynika, że osoby niewidome uzyskały wyższe wyniki w klasach III i V szkoły podstawowej, przy czym w klasie III różnica wyniosła 4 punkty, a w klasie V - 1 punkt, zaś w I gimnazjum zniwelowała się do 0 . Uczniowie niewidomi, tworząc analogie do wyrazu błyskawica, najczęściej odwoływali się do pojęć związanych ze zjawiskami atmosferycznymi, np. piorun, a także do terminów wzrokowych np. jasność, światło. Podobnych odpowiedzi udzielały osoby widzące. Natomiast błędy popełniane przez uczniów niewidomych związane były z terminami dotyczącymi jednej klasy np. deszcz, chmura, niebo, tęcza, grad oraz z terminami odnoszącymi się do wyglądu błyskawicy np. piękny. Jeden uczeń podał, że z błyskawicą pojawia się także widmo. W przypadku uczniów widzących analogiami do terminu błyskawica są również pojęcia związane z pojawianiem się błyskawicy, np. siła, prąd, gorąco, elektrycznie, 
szybko. Troje uczniów widzących podało, że analogią jest słowo frajda. Pozostałe odpowiedzi są zbliżone do wypowiedzi uczniów niewidomych.

Próba 8 (trucizna - śmierć :: pokarm - ...?) wymagała od uczniów wykorzystania wiedzy ogólnej. Pomiędzy trzecioklasistami obu grup nie ma różnic. Jedna i druga grupa osiągnęła po 5 punktów (23,80\%). Natomiast wraz z wiekiem przyrost wyników jest coraz większy, zwłaszcza wśród uczniów niewidomych, którzy w V klasie uzyskali 8 punktów (38,09\%), a w I gimnazjum ponad dwukrotnie więcej, tj. 17 (80,95\%). Tak wysoki wynik świadczy o osiągnięciu przez uczniów stadium myślenia formalnego, w którym wykorzystywane są operacje logiczne. Odnośnie wyników uzyskanych przez uczniów widzących z I klasy gimnazjum, to są one wyższe tylko o 1 punkt w porównaniu z uczniami widzącymi z V klasy. Otrzymali oni 10 punktów (47,61\%). Podstawowe błędne odpowiedzi, jakich udzielili uczniowie niewidomi, związane są z terminami z klasy pojęć, które mają związek ze spożywaniem pokarmu i rodzajami pokarmu np. kasza, spożyć, jedzenie, picie, karmienie. Inne niepoprawne odpowiedzi związane były z użyciem wyrazów przeciwstawnych np. głód. W grupie uczniów widzących odpowiedzi były bardzo podobne.

W próbie 10 (zdarzenie - wspomnienie :: pożar - ...?) uczniowie niewidomi w każdej badanej klasie uzyskali nieznacznie niższe wyniki. W przypadku uczniów niewidomych z klasy III wynik wyniósł 3 punkty (14,28\%), to jest o 2 punkty mniej od widzących rówieśników. Wyniki uczniów z uszkodzonym wzrokiem w klasie V szkoły podstawowej wzrosły o 3 punkty, czyli wyniosły 6 punktów (28,57\%), lecz jest to wynik niższy od uczniów w tym samych wieku, którzy nie posiadają uszkodzonego wzroku, o 4 punkty. Wyniki uzyskane w tej próbie przez uczniów niewidomych uczących się w I klasie gimnazjum wzrosły o 3 punkty, a to oznacza, że uczniowie ci otrzymali 9 punktów (42,85\%). Jeśli chodzi o osoby widzące w wieku 14 lat, wynik pozostał bez zmiany w stosunku do uczniów z klas V. Nieprawidłowe odpowiedzi jakich udzieliły osoby niewidome w pierwszej kolejności związane są z czynnościami i osobami, które biorą udział w gaszeniu pożaru, np. strażak, gaszenie, pompa, metan, woda, ugaszanie, wypadek, podpalenie, dom, łuna, pomoc, las, niebezpieczeństwo, ciepło. W klasach starszych uczniowie niewidomi jako analogie w tej relacji wymieniali wyrazy związane z emocjami, jakie przeżywają ludzie w sytuacji pożaru np. strach, smutek, złe wspomnienia, przerażenie. Błędy popełniane przez uczniów widzących są zbliżone do tych, które popełnili niewidomi.

Próba 12 (instrument - dźwięk :: bomba - ...?) wymagała od uczniów odwołania się do wiedzy odnośnie zjawisk akustycznych. Niezależnie od klasy, do której uczęszczają uczniowie z grupy podstawowej i porównawczej, ci pierwsi uzyskali wyższe rezultaty. Największy przyrost wyników przypada między V klasą 
szkoły podstawowej a I klasą gimnazjum. Różnica ta wyniosła 5 punktów. Wśród odpowiedzi udzielonych przez grupę uczniów niewidomych, do najczęstszych należało odwołanie się do pojęć akustycznych, np. huk, wybuch, grzmot, bum, wysoka głośność, hałas. Typowe błędy odnosiły się do wymieniania poszczególnych rodzajów bomb, np. atomowa, gazowa, zegarowa, petarda. Druga kategoria dotyczy błędów odnoszących się do sytuacji, w których wykorzystuje się bomby, np. zamach, podłożona, strzał, wojna, zegar, niszczenie. Trzecia grupa odnosi się do wyrazów przeciwstawnych, np. cisza. Na czwartą kategorię składają się wyrazy nawiązujące do pierwszej pary, np. basy instrumentów. Osoby widzące udzielały podobnych odpowiedzi jak uczniowie niewidomi.

\section{DYSKUSJA}

Założeniem opisanych badań było empiryczne poznanie i analiza rozumowania przez analogie semantyczne w kategorii przyczyna - skutek u uczniów niewidomych. Dotychczasowe nieliczne badania nad rozumowaniem przez analogie uczniów niewidomych koncentrują się na określeniu, jak przebiega cały ten proces. Pierwszym zagadnieniem, które zostało poddane analizie było określenie, jakie jest rozumowanie przez analogie semantyczne w kategorii przyczyna - skutek u uczniów niewidomych w III i V klasie szkoły podstawowej oraz I klasie gimnazjum. Analiza wyników badań wskazuje na istnienie istotnych statystycznie różnic między uczniami klasy III szkoły podstawowej i I gimnazjum oraz V klasą szkoły podstawowej i I gimnazjum. Oznaczać to może, że wraz z wiekiem rozumowanie przez analogie semantyczne w kategorii przyczyna - skutek w grupie uczniów niewidomych doskonali się, co jest między innymi skutkiem przechodzenia z etapu myślenia konkretnego na etap myślenia formalnego. Następuje wtedy uaktywnienie różnorakich operacji myślowych, w tym coraz precyzyjniejsze wykorzystywanie analogii.

Niniejsze badania dostarczają również informacji na temat istniejących różnic w zakresie rozumowania przez analogie w kategorii przyczyna - skutek między uczniami niewidomymi i widzącymi w III i V klasie szkoły podstawowej oraz I klasie gimnazjum. Okazuje się bowiem, że istotne statystycznie różnice występują tylko między uczniami niewidomymi i widzącymi w wieku 10 lat, czyli uczącymi się w III klasie szkoły podstawowej. Pomiędzy uczniami w V klasie szkoły podstawowej i I gimnazjum nie ma różnic istotnych statystycznie. W obu tych przedziałach relacje semantyczne w kategorii przyczyna - skutek niedostępne poznaniu zmysłowemu uczniowie niewidomi ujmują w taki sam sposób jak uczniowie widzący.

$\mathrm{W}$ rozumowaniu przez analogie semantyczne w kategorii przyczyna - skutek zarówno uczniowie widzący jak i niewidomi osiągnęli stosunkowo niskie wyniki, 
choć rosły one systematycznie wraz z wiekiem. Biorąc pod uwagę wszystkie próby (12), można stwierdzić, że w siedmiu uczniowie niewidomi uzyskali wyższe rezultaty, a w pięciu - niższe. Największe dysproporcje na korzyść niewidomych wystąpiły w próbach dotyczących zjawisk optycznych i stanów emocjonalnych, co zdaje się sugerować, że na te właśnie zagadnienia kładzie się w szkole duży nacisk, dlatego niewidomi dobrze nimi operują.

Błędy popełniane przez uczniów niewidomych i widzących, dotyczące rozumowania przez analogie semantyczne, są bardzo do siebie podobne. Do najczęstszych, niezależnie od kategorii, należą: podawanie negacji zamiast wyrazu odnoszącego się do wymaganej relacji, np. przeciwieństwa, perseweracje wyrazów, stosowanie synonimów i antonimów oraz przypadkowe skojarzenia.

Wyniki powyższych badań zgodne są ze stanowiskiem m.in. B. Pietrulewicza (1983). Dobre wyniki uzyskane przez niewidomych w zakresie relacji semantycznych w kategorii przyczyna - skutek są efektem ich znajomości i rozumienia wyrazów, zasobu pojęciowego, którym się posługują na co dzień, a także umiejętności dokonywania klasyfikacji, porównywania, umiejętności wyznaczania różnic i podobieństw pomiędzy różnymi przedmiotami. Również umiejętności takie np. jak werbalizowanie własnych myśli przyczyniają się do rozumienia zadawanych pytań. Jego zdaniem rozumowanie przez analogie umożliwia niewidomym zdobywanie nowej wiedzy, pozwala na tworzenie obrazu, który jest faktycznym odzwierciedleniem rzeczywistości. W zakresie relacji część-całość osoby niewidome popełniły najmniej błędów. Natomiast najtrudniejsze były te próby, które obejmowały relacje przyczynowo-skutkowe. B. Pietrulewicz wysunął wniosek, że struktury poznawcze, dzięki którym jednostka dokonuje określonej operacji analogicznej, rozwijają się wraz z wiekiem. Również Z. Sękowska (1974), B. Miles i B. McLetchie (2004) oraz K. Jaworska-Biskup (2010) twierdzą, że niewidomi żyją w świecie analogii i dzięki niej poznają rzeczywistość.

\section{ZAKOŃCZENIE}

Zaprezentowane wyżej wyniki badań pozwalają sformułować ważne z psychologicznego i pedagogicznego punktu widzenia wnioski. Rozumowanie przez analogie semantyczne stanowi jeden z głównych sposobów poznawania świata przez niewidomych. Jest tym doskonalsze, im większy jest zakres uczniowskiej wiedzy i doświadczeń. Aby więc doskonalić rozumowanie przez analogie semantyczne, warto zadbać o takie skonstruowanie programów nauczania, by uwzględniały tę specyfikę, a także brały pod uwagę indywidualne potrzeby edukacyjne dziecka. 
Proces tworzenia analogii semantycznych w kategorii przyczyna - skutek nauczyciel powinien wspierać wszelkimi możliwymi metodami. Na pewno może pomóc jak najczęstsze stosowanie metod problemowych na lekcjach, z uaktywnieniem emocji. Jeśli uczeń przebywa w ośrodku, to nawet w trakcie fachowo zorganizowanych zajęć rekreacyjnych można tak dobrać gry i zabawy, aby uaktywniały proces myślenia, uczyły szukania przyczyn i skutków różnych sytuacji. Aby poprawić jakość analogii opartych na materiale semantycznym, potrzeba jak największej ilości ćwiczeń dotykowych na zajęciach lekcyjnych, ale na pewno przydatne też byłyby ćwiczenia $\mathrm{z}$ orientacji przestrzennej $\mathrm{w}$ formie zabawy, w połączeniu $\mathrm{z}$ ruchem, zwłaszcza w młodszych klasach.

Ponieważ nie wszystkie dzieci przebywają w internatach, lecz także w domach rodzinnych, warto uwrażliwiać rodziców na kompensującą i poznawczą rolę wyobrażeń zastępczych, rozumowania przez analogie, o których rozwój należy dbać w różnych sytuacjach życiowych i wykorzystywać przy każdej nadarzającej się ku temu możliwości.

Prezentowane w niniejszym artykule wyniki badań empirycznych oraz wnioski z nich płynące zachęcają do dalszej eksploracji tematu i poszerzania stanu wiedzy na temat rozumowania przez analogie, co jest niezwykle istotne dla zrozumienia procesów poznawczych u osób niewidomych.

\section{LITERATURA}

Iverson J.M, Goldin-Meadow S., 2005, Gesture paves the way for language development. „Psychological Science”, 16:368-371; DOI:10.1111/j.0956-7976.2005.01542.x

Iverson J.M., Goldin-Meadow S., 1997, What's communication got to do with it? Gesture in children blind from birth. „Developmental Psychology”, 33(3), 453-467. http:// dx.doi.org/10.1037/0012-1649.33.3.453

Knauff M., May E, 2006, Mental imagery, reasoning, and blindness. „Quarterly Journal of Experimental Psychology", 59(1), 161-77. DOI: 10.1080/17470210500149992 Knauff M., May E., 2004, Visual imagery in deductive reasoning: Results from experiments with sighted, blindfolded, and congenitally totally blind persons. W: K. Forbus, D. Genter, T. Regier (red.), „Proceedings of the 26th Annual Conference of the Cognitive Science Society", Mahwah, NJ, Erlbaum, s. 708-713.

Jaworska-Biskup K., 2010, Language acquisition in the blind child. Lublin, Wydawnictwo KUL.

Lakoff G., 1990, The invariance hypothesis: is abstract reasoning based on image-schemas? „Cognitive Linguistics”, 1(1), 39-74. DOI: https://doi.org/10.1515/cogl.1990.1.1.39 
Landau B., 1997, Language and experience in blind children: retrospective and perspective. W: V. Lewis, G.M. Collins (red.), „Blindness and psychological development in young children". Leicester, British Psychological Society, s. 9-28.

Miles B., McLetchie B., 2004, Developing concepts with children who are deaf-blind. https://nationaldb.org/ (dostęp: 20.01.2018).

Nęcka E., Orzechowski J., Szymura B., 2006, Psychologia poznawcza. Warszawa, Wydawnictwo Naukowe PWN.

Richland L.E., Morrison R.G, Holyoak K.J., 2006, Children's development of analogical reasoning: Insights from scene analogy problems. „Journal of Experimental Child Psychology", 94, 249-273. DOI:10.1016/j.jecp.2006.02.002

Parulska I. 2010, Wykorzystywanie analogii semantycznych w pracy z uczniem niewidomym.

W: A. Krause, K. Materna, J. Rzeźnicka-Krupa (red.). Życie z niepełnosprawnością - wyzwania edukacyjne, rehabilitacyjne i normalizacyjne. „Dyskursy Pedagogiki Specjalnej” 9, Gdańsk, Fundacja Rozwoju Uniwersytetu Gdańskiego.

Pietrulewicz B., 1983, Rozwój rozumowania przez analogię u dzieci niewidomych.

Wrocław -Łódź, PAN, Komitet Nauk Psychologicznych, Zakład Narodowy Ossolińskich.

Sękowska Z., 1998, Wprowadzenie do pedagogiki specjalnej. Warszawa, Wydawnictwo WSPS.

Walthes R., 2007, Tyflopsychologia. Gdańsk, Wydawnictwo GWP.

\title{
REASONING BY SEMANTIC ANALOGIES OF BLIND STUDENTS \\ IN THE CATEGORY “THE CAUSE - THE EFFECT”
}

\begin{abstract}
Reasoning by analogies plays a huge role in the lives of blind people. Since sighted people use the vocabulary and phrases that capture the relationship between all the senses - the blind must in the best possible way for them to know these phrases. This precisely enables them the analogy. Reasoning by analogies develops and expands vocabulary (active and passive), enables learning about specific relationships between objects, concepts, phenomena, allowing to create more relevant vision of reality. 63 blind students and 63 sighted pupils aged 10-14 years were evaluated. There were used Tests to Examine the Reasoning by Semantic and Numerical Analogies by B. Pietrulewicz. With age, reasoning by semantic analogies of blind students is excelling, which is also due to the transition from concrete thinking to formal stage of thinking. It occurs activation of various mental operations, including the increasingly precise use of analogies.
\end{abstract}

Keywords: analogy, reasoning by semantic analogies, semantic analogies in the category "the cause - the effect", blind students 